\title{
Cytomegalovirus (CMV) shedding is highly correlated with markers of immunosuppression in CMV-seropositive women
}

Correspondence

Michael J. Cannon mcannon@cdc.gov

Received 1 November 2010

Accepted 1 March 2011
Ashley L. Schoenfisch, ${ }^{1}$ Sheila C. Dollard, ${ }^{2}$ Minal Amin, ${ }^{2}$ Lytt I. Gardner, ${ }^{3}$ Robert S. Klein, ${ }^{4}$ Kenneth Mayer, ${ }^{5}$ Anne Rompalo, ${ }^{6}$ Jack D. Sobel ${ }^{7}$ and Michael J. Cannon ${ }^{8}$

${ }^{1}$ Gillings School of Global Public Health, University of North Carolina at Chapel Hill, Chapel Hill, NC, USA

${ }^{2}$ National Center for Immunizations and Respiratory Diseases, Centers for Disease Control and Prevention, Atlanta, GA, USA

${ }^{3}$ National Center for HIV, STD and TB Prevention, Centers for Disease Control and Prevention, Atlanta, GA, USA

${ }^{4}$ Montefiore Medical Center, Albert Einstein College of Medicine, Bronx, NY, USA

${ }^{5}$ Brown University School of Medicine, Providence, RI, USA

${ }^{6}$ Johns Hopkins University, Baltimore, MD, USA

${ }^{7}$ Wayne State School of Medicine, Detroit, MI, USA

${ }^{8}$ National Center on Birth Defects and Developmental Disabilities, Centers for Disease Control and Prevention, Atlanta, GA, USA

Cytomegalovirus (CMV) enters latency following primary infection and can subsequently reactivate. Reinfection with a different viral strain can also occur. During these events, CMV is shed in bodily fluids. This study examined correlates of CMV shedding in specimens obtained from the HIV Epidemiology Research Study, a multicenter cohort study of US women with or at high risk for human immunodeficiency virus (HIV) infection. Among the women studied, $91.4 \%$ (911/997) were CMV IgG seropositive. Of these women, $2.7 \%(25 / 911)$ were CMV IgM seropositive. CMV DNA was detected via real-time PCR more frequently in cervicovaginal lavage (CVL) specimens $(55 / 764,7.2 \%)$ than in peripheral blood mononuclear cells (PBMCs) (26/897, $2.9 \%$ ). CMV viral loads in $1 \mathrm{ml} \mathrm{CVL} \mathrm{(median} \mathrm{534;} \mathrm{mean} \mathrm{2598;} \mathrm{range=40-74} \mathrm{844)} \mathrm{were} \mathrm{higher}$ than in $10^{6}$ PBMCs (median 264; mean 1287; range=35-13 250). CMV DNA in PBMCs was associated with HIV seropositivity [odds ratio (OR) 13.5; $95 \%$ confidence interval (CI) 1.8-100], increasing HIV viral load $(P<0.001$ for trend), decreasing CD4 cell counts $(P<0.001$ for trend) and CMV DNA in CVL (OR 26; $95 \% \mathrm{Cl} 10.7-64)$. CMV DNA in CVL specimens was associated with CMV IgM seropositivity (OR 4.3; $95 \%$ Cl 1.5-12.3), HIV seropositivity (OR 7.3; $95 \% \mathrm{Cl}$ 2.6-20), increasing HIV viral load ( $P<0.001$ for trend) and decreasing CD4 cell counts $(P<0.001$ for trend). The positive predictive value of CMV IgM seropositivity for CMV DNA shedding in either PBMCs or CVL was $20 \%$. In summary, CMV shedding in CVL and PBMCs was highly correlated with each other and with markers of immune suppression.

\section{INTRODUCTION}

Cytomegalovirus (CMV) is a herpesvirus that generally does not cause disease in immunocompetent individuals

Abbreviations: $\mathrm{Cl}$, confidence interval; $\mathrm{CMV}$, cytomegalovirus; $\mathrm{CVL}$, cervicovaginal lavage; $\mathrm{HCV}$, hepatitis $\mathrm{C}$ virus; HERS, HIV Epidemiology Research Study; HIV, human immunodeficiency virus; HSV, herpes simplex virus; OR, odds ratio; PBMC, peripheral blood mononuclear cell. but is responsible for substantial morbidity and mortality among human immunodeficiency virus (HIV)-infected persons (Emery et al., 1999), transplant recipients (Cope et al., 1997) and congenitally infected children (Cannon \& Davis, 2005). Compared with CMV infection in HIVinfected individuals and transplant recipients, less progress has been made in the prevention of congenital CMV disease (de Jong et al., 1998; Read et al., 2008), despite a 
huge physical, emotional and financial burden (Stratton et al., 2000). Specifically, 30000-40 000 US children are born with congenital CMV infection annually, causing at least 150 deaths and leaving more than 5500 children with disabilities such as hearing or vision loss, or cognitive disability (i.e. mental retardation) (Dollard et al., 2007; Grosse et al., 2008; Kenneson \& Cannon, 2007).

Like other herpesviruses, CMV enters latency following primary infection but can subsequently reactivate (Mocarski et al., 2007). Active virus replication is characteristic of primary infection, reactivation and reinfection with a different CMV strain, but such replication is suppressed during latency. Among pregnant women, virus replication in uterine and placental compartments is probably necessary for fetal infection to occur (Pereira et al., 2005). Because virus replication in these internal compartments is not easily measured, it is important to identify a useful surrogate marker. One potential marker is virus replication in peripheral bodily fluids, such as blood or cervicovaginal secretions, commonly referred to as 'shedding'.

However, the occurrence of CMV shedding in bodily fluids is poorly understood. In particular, it is important to gain a better understanding of the frequency of CMV shedding in adults, the likelihood of shedding in different bodily fluids, the viral loads in these fluids and the factors associated with shedding. The purpose of this study was to address these questions in a large cohort of women of reproductive age.

\section{METHODS}

Study design and population. Participants were enrolled in the HIV Epidemiology Research Study (HERS), a multicenter cohort study of women with or at high risk of HIV infection (Smith et al., 1997; Stover et al., 2003). Recruitment, screening and enrolment for the HERS took place from April 1993 to January 1995. Follow-up visits took place at 6 month intervals. Visits included an extensive interview, a general physical and pelvic examination, and biological specimen collection. For this study, participant visits were stratified on HIV status and CD4 cell count and were selected randomly, one visit per participant, with the sample enriched by a small group of participant visits from women who were pregnant. A total of 997 participant visits were included. Stored serum, peripheral blood mononuclear cells (PBMCs) and cervicovaginal lavage (CVL) specimens were retrieved subject to availability. Informed consent was obtained from all participants and the study was approved by the institutional review boards from each of the authors' institutions.

CMV laboratory methods. All specimens were stored by the HERS repository at $-80^{\circ} \mathrm{C}$ until transport to the testing laboratory in 2005. Specimens were thawed once, tested for other purposes, refrozen and stored at $-20^{\circ} \mathrm{C}$ for $4-6$ months, and then tested for CMV DNA for the current study. CMV IgG and IgM antibodies were detected in serum using a VIDAS automated immunoassay test (BioMéreiux). Total CMV DNA was extracted from PBMCs and unfractionated CVL specimens using a MagNAPure automated extractor (Roche). CMV PCR used Taqman reagents (Applied Biosystems) and targeted the viral glycoprotein B gene (Boppana et al., 2005). Results were interpreted as described by Kharrazi et al.
(2010). Specimens were tested in duplicate, and cycle thresholds of $\leqslant 40$ for both reactions were required to report a specimen as positive.

Statistical analysis. Among CMV IgG-seropositive women, univariate risk factors were examined for CMV DNA shedding in PBMCs and CVL. The variables selected included CMV IgM, demographic variables, variables associated with immunosuppression, and markers of active infection (chlamydia, bacterial vaginosis, syphilis and gonorrhoea) or seropositivity [herpes simplex virus type 2 (HSV-2) and hepatitis $\mathrm{C}$ virus (HCV)]. In multivariate analyses, base models included all variables that were associated with CMV shedding in univariate analyses with $P<0.10$. CMV IgM was included in all models because of its a priori importance. IgM antibody is often used as a marker for active infection because it is present briefly during primary infection and is believed to be generated again by reinfection with a new CMV strain. Due to strong correlation between CD4 count and HIV viral load, these two variables were not included simultaneously in the same model. Each of the other variables was added individually and retained only if it had a $P<0.10$ or if $\ln$ $\left(\mathrm{OR}_{\text {without variable of interest }} / \mathrm{OR}_{\mathrm{with}}\right.$ variable of interest $)$ was greater than $10 \%$ for all levels of any base variable $(\mathrm{OR}=$ odds ratio). Given the small cell sizes, effect measure modification was not assessed. All analyses were performed using SAS v9.2 (SAS Institute).

\section{RESULTS}

The 997 women in this study were evenly distributed among the study cities and ranged in age from 17 to 60 years (median 36 years). The majority of the women were black $(61.0 \%)$, followed by white $(19.9 \%)$ and Hispanic (17.9\%). After oversampling for pregnancy visits, $8.8 \%$ of the women were pregnant at the time of their visit. Nearly one in five women had used injection drugs in the 6 months prior to their visit or since their previous visit. The most common infections among the women were HIV (66.2\%), HCV (55.9\%), HSV-1 $(76.0 \%)$ and HSV-2 $(66.1 \%)$. Less common infections included bacterial vaginosis $(40.0 \%)$, syphilis $(10.7 \%)$, chlamydia $(4.2 \%)$ and gonorrhoea $(<1 \%)$.

CMV IgG antibody was detected in $91.4 \%$ (911/997) of the study subjects. Of these 911 women, $2.7 \%$ (25/911) were CMV IgM seropositive (Tables 1 and 2). The positive predictive value of CMV IgM seropositivity for CMV shedding in PBMCs or CVL was $20 \%(5 / 25)$. CMV DNA was detected more frequently in CVL specimens (55/764, $7.2 \%)$ than in PBMCs $(26 / 897,2.9 \%)$. CMV viral loads in blood were 35-13250 copies of viral DNA (median 264; mean 1287) per $10^{6}$ PBMCs. CMV viral loads in CVL specimens were 40-74 844 copies (median 534; mean 2598) $\mathrm{ml}^{-1}$.

In univariate analyses (Tables 1 and 2), the presence of CMV DNA in PBMCs was most strongly associated with the presence of CMV DNA in CVL, HIV seropositivity, higher HIV viral load and lower CD4 count. The presence of CMV DNA in PBMCs was also associated with having sex with a male in the past 6 months. The presence of CMV DNA in CVL was most strongly associated with the presence of CMV DNA in PBMCs, HIV seropositivity, higher HIV viral load, lower CD4 count, CMV IgM 
Table 1. Univariate analyses of CMV DNA in PBMC specimens in CMV IgG-seropositive women

Data were not available for all women for all variables.

\begin{tabular}{|c|c|c|c|c|}
\hline Variable & No. of women & $\begin{array}{c}\text { CMV DNA in PBMCs } \\
{[n(\%)]}\end{array}$ & OR $(95 \% \mathrm{CI})$ & $P$ value \\
\hline \multicolumn{5}{|l|}{ CMV DNA in CVL } \\
\hline No & 695 & $9(1.3)$ & 1 & \\
\hline Yes & 55 & $14(25.5)$ & $26(10.7-64)$ & $<0.001$ \\
\hline \multicolumn{5}{|l|}{ CMV IgM } \\
\hline Seronegative & 872 & $24(2.8)$ & 1 & \\
\hline Seropositive & 25 & $2(8.0)$ & $3.1(0.7-13.8)$ & 0.12 \\
\hline \multicolumn{5}{|l|}{ Age at visit } \\
\hline$\geqslant 42$ years & 222 & $5(2.3)$ & 1 & \\
\hline $37-41$ years & 217 & $7(3.2)$ & $1.5(0.5-4.6)$ & 0.53 \\
\hline $32-36$ years & 247 & $10(4.0)$ & $1.8(0.6-5.4)$ & 0.27 \\
\hline$<32$ years & 211 & $4(1.9)$ & $0.8(0.2-3.2)$ & 0.80 \\
\hline \multicolumn{5}{|l|}{ Pregnancy status } \\
\hline Not pregnant & 811 & $25(3.1)$ & 1 & \\
\hline Pregnant & 80 & $1(1.3)$ & $0.4(0.05-3.0)$ & 0.35 \\
\hline \multicolumn{5}{|l|}{ HIV status } \\
\hline Seronegative & 306 & $1(0.3)$ & 1 & \\
\hline Seropositive & 591 & $25(4.2)$ & $13.5(1.8-100)$ & 0.001 \\
\hline \multicolumn{5}{|l|}{ HIV viral load } \\
\hline 0 (HIV negative) & 306 & $1(0.3)$ & 1 & \\
\hline$<1000$ & 154 & $1(0.6)$ & $2.0(0.1-32)$ & \\
\hline $1000-10000$ & 175 & $3(1.7)$ & $5.3(0.6-52)$ & \\
\hline$\geqslant 10000$ & 195 & $18(9.2)$ & $31(4.1-234)$ & $<0.001^{\star}$ \\
\hline \multicolumn{5}{|l|}{ CD4 cell count } \\
\hline$\geqslant 500$ & 485 & $2(0.4)$ & 1 & \\
\hline $200-499$ & 231 & $3(1.3)$ & $3.2(0.5-19.1)$ & \\
\hline $51-199$ & 134 & $10(7.5)$ & $19.5(4.2-90)$ & \\
\hline$\leqslant 50$ & 47 & $11(23.4)$ & $74(15.8-345)$ & $<0.001^{\star}$ \\
\hline \multicolumn{5}{|c|}{$\begin{array}{l}\text { Sex with male in past } 6 \\
\text { months }\end{array}$} \\
\hline No & 219 & $12(5.5)$ & 1 & \\
\hline Yes & 645 & $13(2.0)$ & $0.4(0.2-0.8)$ & 0.008 \\
\hline \multicolumn{5}{|l|}{ Injection drug use $\dagger$} \\
\hline No & 720 & $22(3.1)$ & 1 & \\
\hline Yes & 165 & $4(2.4)$ & $0.79(0.27-2.32)$ & 0.67 \\
\hline \multicolumn{5}{|l|}{ Chlamydia $\ddagger$} \\
\hline Negative & 684 & $20(2.9)$ & 1 & \\
\hline Positive & 30 & $0(0)$ & $-(-)$ & - \\
\hline \multicolumn{5}{|l|}{ Bacterial vaginosis $\ddagger$} \\
\hline No & 527 & $17(3.2)$ & 1 & \\
\hline Yes & 350 & $9(2.6)$ & $0.8(0.3-1.8)$ & 0.58 \\
\hline \multicolumn{5}{|l|}{ HSV-2‡ } \\
\hline Seronegative & 297 & $12(4.0)$ & 1 & \\
\hline Seropositive & 578 & $14(2.4)$ & $0.6(0.3-1.3)$ & 0.18 \\
\hline \multicolumn{5}{|l|}{$\mathrm{HCV} \ddagger$} \\
\hline Seronegative & 374 & $12(3.2)$ & 1 & \\
\hline Seropositive & 471 & $12(2.5)$ & $0.8(0.4-1.8)$ & 0.57 \\
\hline
\end{tabular}

${ }^{\star}$ Test for linear trend.

$\dagger$ Injected drugs included speedball, cocaine, heroin, amphetamines and other opiates injected since the last visit or within the previous 6 months. $\ddagger$ Result from enrolment visit. 
Table 2. Univariate analyses of CMV DNA in CVL specimens in CMV IgG-seropositive women

Data were not available for all women for all variables.

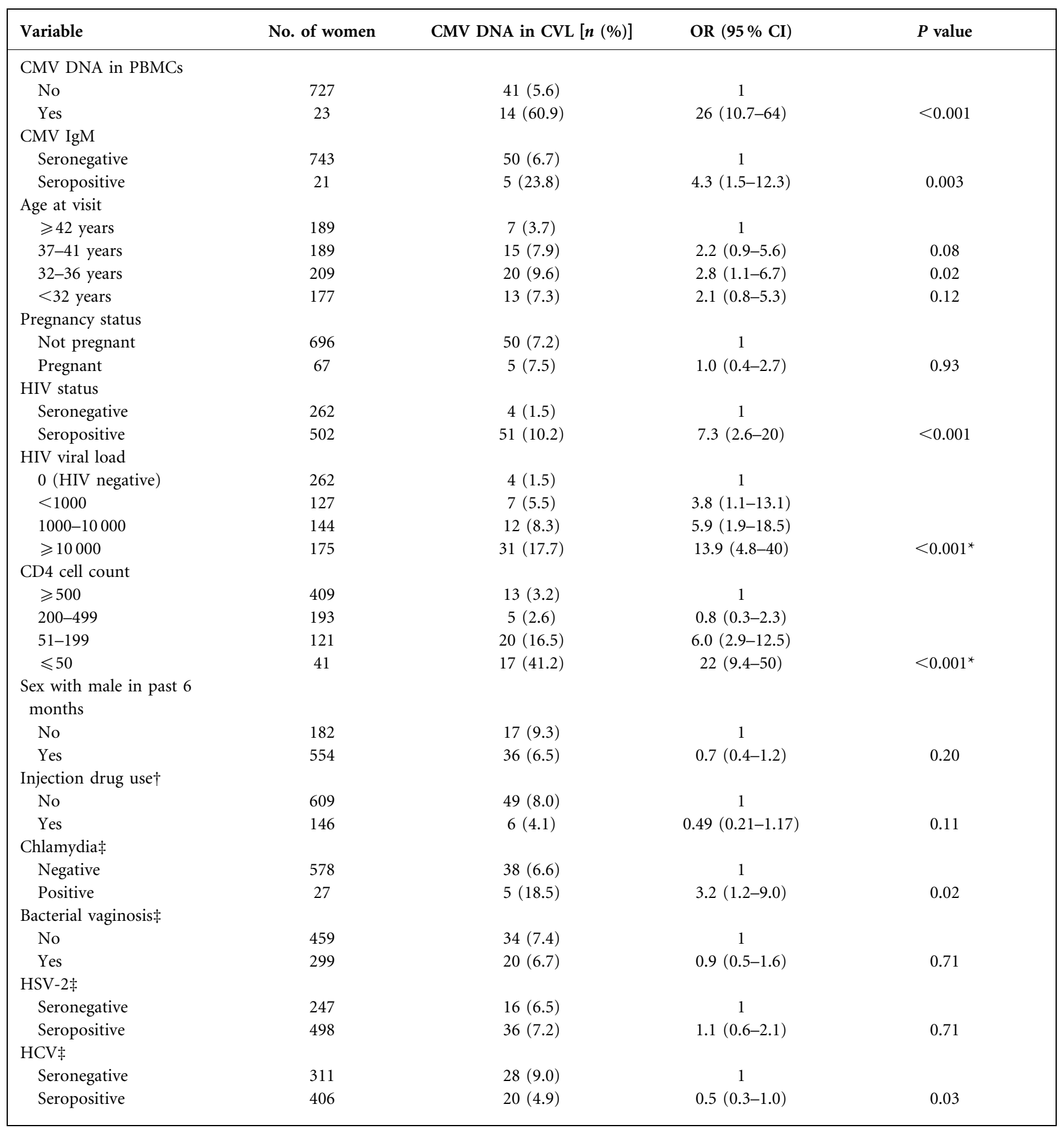

${ }^{*}$ Test for linear trend.

$\dagger$ Injected drugs included speedball, cocaine, heroin, amphetamines and other opiates injected since the last visit or within the previous 6 months. ‡Result from enrolment visit.

seropositivity, a younger age, the presence of chlamydia and the presence of HCV antibody. For both PBMCs and $\mathrm{CVL}$, the association of CMV shedding with increasing
HIV viral load and decreasing CD4 cell count had a strong biological gradient $(P<0.001$ for trend in all cases). Women who were missing PBMCs or CVL were similar 
to those who had available PBMCs or CVL with regard to HIV serostatus, HIV viral load and CD4 count (data not shown).

In multivariate analyses (models not shown), the strongest risk factors $(P<0.001$ for trend) for CMV shedding were the markers of immunosuppression (i.e. low CD4 count and high HIV viral load). For CMV in PBMCs, shedding was significantly less likely if the woman was HSV-2 seropositive $[\mathrm{OR}=0.4 ; 95 \%$ confidence interval $(\mathrm{CI}) 0.2-$ $0.9]$. For CMV in CVL, shedding was significantly more likely if CMV IgM (OR=4.9; $95 \%$ CI 1.1-22) or chlamydia $(\mathrm{OR}=4.8 ; 95 \%$ CI 1.4-16.5) were present. However, due to the small numbers in some variable categories, CIs tended to be very wide for all variables in the multivariate analyses.

\section{DISCUSSION}

In this, one of the largest studies to examine risk factors for CMV DNA shedding, shedding in CVL or PBMCs was found to occur in a low proportion of women. When CMV shedding did occur, it was more frequent in CVL than in PBMCs, although shedding in the two specimen types was highly correlated. Viral loads were also higher in CVL than in PBMCs. However, viral loads were relatively low for both specimens, suggesting some degree of control by the immune system. It is not known why CMV shedding occurs more frequently in some specimen types than in others. Previous studies of adults have found that CMV shedding is usually more frequent in genital secretions or urine than in blood (Kaye et al., 2008; Novak et al., 2008; Spano et al., 2004; Zanghellini et al., 1999).

The prevalence of CMV shedding in CVL in this study was at the lower end of the range compared with other studies, where estimates typically ranged from $\sim 5$ to $\geqslant 30 \%$ (Bello \& Whittle, 1991; Biri et al., 2006; Broccolo et al., 2008; Chandler et al., 1985; Clarke et al., 1996; Collier et al., 1995; Demmler et al., 1987; Kaye et al., 2008; Numazaki et al., 1970; Pass et al., 1982; Shen et al., 1993a, c; Spano et al., 2004; Stagno et al., 1975; Tanaka et al., 2006; Zanghellini et al., 1999). The high variability in CMV shedding in CVL across these studies may be due in part to differences in geography or the type of population studied, with many of the highest estimates coming from populations enrolled at sexually transmitted disease clinics. Based on some of these previous studies, one might expect a higher prevalence of CMV shedding among a population with HIV or HIV risk factors. However, the enrolment criteria of the HERS included women with moderate sexual activity (five partners in total over 5 years) such that many of the study participants did not have a history of high sexual risk activity and did not have sexually transmitted diseases (Cannon et al., 2001; Smith et al., 1997). Nevertheless, the pattern of CMV shedding in this population should not be presumed to be representative of that which might be found in the general population. An additional limitation of the study was the retrospective design and use of archived specimens such that it was not possible to conduct tissue culture on clinical specimens to determine the proportion of CMV DNA that was infectious virus.

The relatively low prevalence of CMV DNA positivity we found may have been due in part to the long-term storage of specimens and the single freeze-thaw cycle prior to testing, but we would expect only slight DNA degradation under these storage conditions. Another possible contributor to the lower prevalence may have been the use of an automated DNA extraction method (MagNA Pure; Roche), which was the best available DNA extractor at the time but which has since been replaced by methods providing higher yields of DNA. The lower prevalence may also have been related to testing of CVL specimens rather than cervical swabs, which have shown higher sensitivity for HIV RNA and HSV-2 DNA (Delany et al., 2008).

The strongest risk factors for CMV shedding were markers of immunosuppression such as HIV seropositivity, high HIV viral load and low CD4 cell count. These associations showed a strong biological gradient, with shedding prevalence substantially increasing as HIV viral load increased and CD4 cell count decreased. These findings emphasize the fundamental role of immune control in maintaining CMV latency and represent one of the largestscale in vivo demonstrations of such a role. The infrequency of CMV shedding in immunocompetent adults suggests that adult-to-adult transmission may be much more frequent when the source adult is immunocompromised. Alternatively, CMV transmission may be driven primarily by recently infected adults whose immune system has not yet brought the virus under control (Coonrod et al., 1998; Natali et al., 1997; Revello et al., 1998; Zhang et al., 2006).

Although the pregnant women in this study did not have an elevated risk of CMV shedding, the overall frequencies of shedding and pregnancy were too low to assess this risk adequately. Other studies have found that CMV shedding increases with advancing gestational age (Shen et al., 1993b; Stagno et al., 1975), but no studies have shown whether pregnancy itself is a risk factor for shedding. Presumably the altered immune response during pregnancy could lead to lack of immune control and subsequent reactivation of CMV (Szekeres-Bartho, 2002). Such increased risk of shedding during pregnancy could be responsible for transmission to the fetus among women who are CMV seropositive prior to conception.

CMV IgM antibody was found in $2.7 \%$ of the CMV IgGseropositive women. Most women who were IgM positive did not have detectable CMV DNA in their PBMCs or CVL; the positive predictive value of IgM for CMV shedding was only $20 \%$. Several factors may have contributed to the low correlation of $\operatorname{IgM}$ and viral shedding, including the relatively low viral loads seen in this study, intermittent shedding typical of CMV infection (Griffiths et al., 1978; Nankervis et al., 1984; Rosenthal et al., 2009), persistence of IgM after virus replication has 
ceased (Kangro et al., 1982) and limitations in sensitivity and specificity of CMV IgM assays (Lazzarotto et al., 1992). Whatever the reason, CMV IgM positivity may be a poor marker for active CMV replication.

Finally, CMV shedding in CVL but not PBMCs was associated with the presence of chlamydia. CMV shedding in CVL was not associated with bacterial vaginosis, in contrast to findings from a smaller study of CMV genital tract shedding (Ross et al., 2005). Nevertheless, various studies have shown that $\mathrm{CMV}$ is associated with the presence of genital tract infections, and that interaction among these agents could be occurring, perhaps mediated through low-grade inflammation or other immunomodulatory effects (Chandler et al., 1987; Coonrod et al., 1998; Fowler \& Pass, 1991; Pereira et al., 1990; Shen et al., 1994). Such interactions could increase the potential for sexual transmission of infections such as CMV and HIV.

\section{ACKNOWLEDGEMENTS}

We thank Pangaja Paramsothy for assistance with the HERS dataset. The findings and conclusions in this report are those of the authors and do not necessarily represent the official position of the Centers for Disease Control and Prevention.

\section{REFERENCES}

Bello, C. \& Whittle, H. (1991). Cytomegalovirus infection in Gambian mothers and their babies. J Clin Pathol 44, 366-369.

Biri, A., Bozdayi, G., Ciçfti, B., Dinç, B., Yücel, A. \& Rota, S. (2006). The detection of CMV in amniotic fluid and cervicovaginal smear samples by real-time PCR assay in prenatal diagnosis. Arch Gynecol Obstet 273, 261-266.

Boppana, S. B., Fowler, K. B., Pass, R. F., Rivera, L. B., Bradford, R. D., Lakeman, F. D. \& Britt, W. J. (2005). Congenital cytomegalovirus infection: association between virus burden in infancy and hearing loss. J Pediatr 146, 817-823.

Broccolo, F., Cassina, G., Chiari, S., Garcia-Parra, R., Villa, A., Leone, B. E., Brenna, A., Locatelli, G., Mangioni, C. \& Cocuzza, C. E. (2008). Frequency and clinical significance of human $\beta$-herpesviruses in cervical samples from Italian women. J Med Virol 80, 147-153.

Cannon, M. J. \& Davis, K. F. (2005). Washing our hands of the congenital cytomegalovirus disease epidemic. BMC Public Health 5, 70.

Cannon, M. J., Dollard, S. C., Smith, D. K., Klein, R. S., Schuman, P., Rich, J. D., Vlahov, D. \& Pellett, P. E. for the HIV Epidemiology Research Study Group (2001). Blood-borne and sexual transmission of human herpesvirus 8 in women with or at risk for human immunodeficiency virus infection. $N$ Engl J Med 344, 637-643.

Chandler, S. H., Holmes, K. K., Wentworth, B. B., Gutman, L. T., Wiesner, P. J., Alexander, E. R. \& Handsfield, H. H. (1985). The epidemiology of cytomegaloviral infection in women attending a sexually transmitted disease clinic. J Infect Dis 152, 597-605.

Chandler, S. H., Handsfield, H. H. \& McDougall, J. K. (1987), Isolation of multiple strains of cytomegalovirus from women attending a clinic for sexually transmitted disease. J Infect Dis 155, 655-660.

Clarke, L. M., Duerr, A., Feldman, J., Sierra, M. F., Daidone, B. J. \& Landesman, S. H. (1996). Factors associated with cytomegalovirus infection among human immunodeficiency virus type 1-seronegative and -seropositive women from an urban minority community. J Infect Dis 173, 77-82.

Collier, A. C., Handsfield, H. H., Ashley, R., Roberts, P. L., DeRouen, T., Meyers, J. D. \& Corey, L. (1995). Cervical but not urinary excretion of cytomegalovirus is related to sexual activity and contraceptive practices in sexually active women. $J$ Infect Dis 171, 33-38.

Coonrod, D., Collier, A. C., Ashley, R., DeRouen, T. \& Corey, L. (1998). Association between cytomegalovirus seroconversion and upper genital tract infection among women attending a sexually transmitted disease clinic: a prospective study. J Infect Dis 177, 11881193.

Cope, A. V., Sweny, P., Sabin, C., Rees, L., Griffiths, P. D. \& Emery, V. C. (1997). Quantity of cytomegalovirus viruria is a major risk factor for cytomegalovirus disease after renal transplantation. J Med Virol 52, 200-205.

de Jong, M. D., Boucher, C. A. B., Danner, S. A., Gazzard, B., Griffiths, P. D., Katlama, C., Lange, J. M. A., Richman, D. D. \& Vella, S. (1998). Summary of the international consensus symposium on management of HIV, CMV and hepatitis virus infections. Antiviral Res 37, 1-16.

Delany, S., Rosas, R., Mlaba, N., Clayton, T., Akpomiemie, G., LeGoff, J., Capovilla, A., Bélec, L., Stevens, W. \& Mayaud, P. (2008). Comparison of cervicovaginal lavage, cervicovaginal lavage enriched with cervical swab, and vaginal tampon for the detection of HIV-1 RNA and HSV-2 DNA in genital secretions. J Acquir Immune Defic Syndr 49, 406409.

Demmler, G. J., Yow, M. D., Spector, S. A., Reis, S. G., Brady, M. T., Anderson, D. C. \& Taber, L. H. (1987). Nosocomial cytomegalovirus infections within two hospitals caring for infants and children. J Infect Dis 156, 9-16.

Dollard, S. C., Grosse, S. D. \& Ross, D. S. (2007). New estimates of the prevalence of neurological and sensory sequelae and mortality associated with congenital cytomegalovirus infection. Rev Med Virol 17, 355-363.

Emery, V. C., Sabin, C., Feinberg, J. E., Grywacz, M., Knight, S. \& Griffiths, P. D. for the AIDS Clinical Trials Group 204/Glaxo Wellcome 123-014 International CMV Prophylaxis Study Group (1999). Quantitative effects of valacyclovir on the replication of cytomegalovirus (CMV) in persons with advanced human immunodeficiency virus disease: baseline CMV load dictates time to disease and survival. J Infect Dis 180, 695-701.

Fowler, K. B. \& Pass, R. F. (1991). Sexually transmitted diseases in mothers of neonates with congenital cytomegalovirus infection. J Infect Dis 164, 259-264.

Griffiths, P. D., Stagno, S., Reynolds, D. W. \& Alford, C. A. (1978). A longitudinal study of the serological and virological status of 18 women infected with cytomegalovirus. Arch Virol 58, 111-118.

Grosse, S. D., Ross, D. S. \& Dollard, S. C. (2008). Congenital cytomegalovirus (CMV) infection as a cause of permanent bilateral hearing loss: a quantitative assessment. J Clin Virol 41, 57-62.

Kangro, H. O., Griffiths, P. D., Huber, T. J. \& Heath, R. B. (1982). Specific IgM class antibody production following infection with cytomegalovirus. J Med Virol 10, 203-212.

Kaye, S., Miles, D., Antoine, P., Burny, W., Ojuola, B., Kaye, P., Rowland-Jones, S., Whittle, H., van der Sande, M. \& Marchant, A. (2008). Virological and immunological correlates of mother-to-child transmission of cytomegalovirus in The Gambia. J Infect Dis 197, 1307-1314.

Kenneson, A. \& Cannon, M. J. (2007). Review and meta-analysis of the epidemiology of congenital cytomegalovirus (CMV) infection. Rev Med Virol 17, 253-276. 
Kharrazi, M., Hyde, T., Young, S., Amin, M. M., Cannon, M. J. \& Dollard, S. C. (2010). Use of screening dried blood spots for estimation of prevalence, risk factors, and birth outcomes of congenital cytomegalovirus infection. J Pediatr 157, 191-197.

Lazzarotto, T., Dalla Casa, B., Campisi, B. \& Landini, M. P. (1992). Enzyme-linked immunoadsorbent assay for the detection of cytomegalovirus-IgM: comparison between eight commercial kits, immunofluorescence, and immunoblotting. J Clin Lab Anal 6, 216-218.

Mocarski, E. S., Jr, Shenk, T. \& Pass, R. F. (2007). Cytomegaloviruses. In Fields Virology, 5th edn, pp. 2702-2772. Edited by D. M. Knipe \& P. M. Howley. Philadelphia: Lippincott Williams \& Wilkins.

Nankervis, G. A., Kumar, M. L., Cox, F. E. \& Gold, E. (1984). A prospective study of maternal cytomegalovirus infection and its effect on the fetus. Am J Obstet Gynecol 149, 435-440.

Natali, A., Valcavi, P., Medici, M. C., Dieci, E., Montali, S. \& Chezzi, C. (1997). Cytomegalovirus infection in an Italian population: antibody prevalence, virus excretion and maternal transmission. New Microbiol 20, 123-133.

Novak, Z., Ross, S. A., Patro, R. K., Pati, S. K., Kumbla, R. A., Brice, S. \& Boppana, S. B. (2008). Cytomegalovirus strain diversity in seropositive women. J Clin Microbiol 46, 882-886.

Numazaki, Y., Yano, N., Morizuka, T., Takai, S. \& Ishida, N. (1970). Primary infection with human cytomegalovirus: virus isolation from healthy infants and pregnant women. Am J Epidemiol 91, 410-417.

Pass, R. F., Stagno, S., Dworsky, M. E., Smith, R. J. \& Alford, C. A. (1982). Excretion of cytomegalovirus in mothers: observations after delivery of congenitally infected and normal infants. J Infect Dis 146, $1-6$.

Pereira, L. H., Embil, J. A., Haase, D. A. \& Manley, K. M. (1990). Cytomegalovirus infection among women attending a sexually transmitted disease clinic: association with clinical symptoms and other sexually transmitted diseases. Am J Epidemiol 131, 683-692.

Pereira, L., Maidji, E., McDonagh, S. \& Tabata, T. (2005). Insights into viral transmission at the uterine-placental interface. Trends Microbiol 13, 164-174.

Read, J. S., Cannon, M. J., Stanberry, L. R. \& Schuval, S. (2008). Prevention of mother-to-child transmission of viral infections. Curr Probl Pediatr Adolesc Health Care 38, 274-297.

Revello, M. G., Zavattoni, M., Sarasini, A., Percivalle, E., Simoncini, L. \& Gerna, G. (1998). Human cytomegalovirus in blood of immunocompetent persons during primary infection: prognostic implications for pregnancy. J Infect Dis 177, 1170-1175.

Rosenthal, L. S., Fowler, K. B., Boppana, S. B., Britt, W. J., Pass, R. F., Schmid, S. D., Stagno, S. \& Cannon, M. J. (2009). Cytomegalovirus shedding and delayed sensorineural hearing loss: results from longitudinal follow-up of children with congenital infection. Pediatr Infect Dis J 28, 515-520.

Ross, S. A., Novak, Z., Ashrith, G., Rivera, L. B., Britt, W. J., Hedges, S., Schwebke, J. R. \& Boppana, A. S. (2005). Association between genital tract cytomegalovirus infection and bacterial vaginosis. J Infect Dis 192, $1727-1730$.
Shen, C.-Y., Chang, S.-F., Chao, M.-F., Huang, E.-S. \& Wu, C.-W. (1993a). Identification of a serial change in recurrent cytomegalovirus strains in a healthy child by polymerase chain reaction. J Infect Dis 168, 252-253.

Shen, C.-Y., Chang, S.-F., Yen, M.-S., Ng, H.-T., Huang, E.-S. \& Wu, C.-W. (1993b). Cytomegalovirus excretion in pregnant and nonpregnant women. J Clin Microbiol 31, 1635-1636.

Shen, C.-Y., Chang, S.-F., Chao, M.-F., Yang, S.-L., Lin, G.-M., Chang, W.-W., Wu, C.-W., Yen, M.-S., Ng, H.-T. \& other authors (1993c). Cytomegalovirus recurrence in seropositive pregnant women attending obstetric clinics. J Med Virol 41, 24-29.

Shen, C.-Y., Chang, S.-F., Lin, H.-J., Ho, H.-N., Yeh, T.-S., Yang, S.-L., Huang, E.-S. \& Wu, C.-W. (1994). Cervical cytomegalovirus infection in prostitutes and in women attending a sexually transmitted disease clinic. J Med Virol 43, 362-366.

Smith, D. K., Warren, D. L., Vlahov, D., Schuman, P., Stein, M. D., Greenberg, B. L. \& Holmberg, S. D. (1997). Design and baseline participant characteristics of the Human Immunodeficiency Virus Epidemiology Research (HER) Study: a prospective cohort study of human immunodeficiency virus infection in US women. Am J Epidemiol 146, 459-469.

Spano, L. C., Gatti, J., Nascimento, J. P. \& Leite, J. P. (2004). Prevalence of human cytomegalovirus infection in pregnant and nonpregnant women. J Infect 48, 213-220.

Stagno, S., Reynolds, D., Tsiantos, A., Fuccillo, D. A., Smith, R., Tiller, M. \& Alford, C. A., Jr (1975). Cervical cytomegalovirus excretion in pregnant and nonpregnant women: suppression in early gestation. J Infect Dis 131, 522-527.

Stover, C. T., Smith, D. K., Schmid, D. S., Pellett, P. E., Stewart, J. A., Klein, R. S., Mayer, K., Vlahov, D., Schuman, P. \& other authors (2003). Prevalence of and risk factors for viral infections among human immunodeficiency virus (HIV)-infected and high-risk HIVuninfected women. J Infect Dis 187, 1388-1396.

Stratton, K. R., Durch, J. S. \& Lawrence, R. S. (editors) (2000). Vaccines for the 21st Century: A Tool for Decision Making. Washington, DC: National Academy Press.

Szekeres-Bartho, J. (2002). Immunological relationship between the mother and the fetus. Int Rev Immunol 21, 471-495.

Tanaka, K., Yamada, H., Minami, M., Kataoka, S., Numazaki, K., Minakami, H. \& Tsutsumi, H. (2006). Screening for vaginal shedding of cytomegalovirus in healthy pregnant women using real-time PCR: correlation of CMV in the vagina and adverse outcome of pregnancy. J Med Virol 78, 757-759.

Zanghellini, F., Boppana, S. B., Emery, V. C., Griffiths, P. D. \& Pass, R. F. (1999). Asymptomatic primary cytomegalovirus infection: virologic and immunologic features. J Infect Dis 180, 702-707.

Zhang, C., Buchanan, H., Andrews, W., Evans, A. \& Pass, R. F. (2006). Detection of cytomegalovirus infection during a vaccine clinical trial in healthy young women: seroconversion and viral shedding. J Clin Virol 35, 338-342. 